\title{
ANALYSIS OF PHONOLOGICAL ERRORS IN TODDLERS: CASE STUDY CHILDREN AGES 2-2.5 YEARS
}

\author{
Endang Sri Andayani \\ Universitas Bina Sarana Informatika, Jakarta \\ Email: endang.erz@bsi.ac.id
}

\begin{abstract}
We can be sure that humans speak whatever they do, whether they drive, play, work or make friends. People live in the linguistic world. Everybody may interact with their families, colleagues, teachers or even strangers in human language. The study took place in Bandung in May 2021. The tool used in this research is a qualitative method with an application to case studies. In kids aged 2-2 years six months, the data source has been collected from an FA child using qualitative methods. The design of the study was longitudinal. The FA has obtained research data through observations, notes and interviews between the FA and its parents. The results of this article indicate that the phoneme [a], I [u], [o], [alternative], [alternative], [alternatively] and [alternative] is mastered by TPM. At the age of 2 years and one month, he mastered vocal phonemes. The first vowels he learned were the [a], I [u], I then the front vowels I [e], [T], [o], [first], [middle vowel] [first], [a]. Vowels not diphenic in nature were, for instance [au], [ai] and [ue], also mastered at the age of 2 years and three months. However, the initial [au] and [ai] diphthongs were not perfected until they were two years old and six months old. At the same time, there is a good deal of mastery in the consonants $[\mathrm{p}],[\mathrm{b}],[\mathrm{t}],[\mathrm{t}],[\mathrm{h}],[\mathrm{j}],[\mathrm{n}],[\mathrm{p}],[\mathrm{p}],[\mathrm{l}],[\mathrm{f}]$, and $[\mathrm{y}]$. The $[\mathrm{t}],[\mathrm{s}],[\mathrm{c}],[\mathrm{j}]$ and [alias] consonants have been found but still fluctuate in other sounds. The tone of the Velar $[\mathrm{g}],[\mathrm{k}]$ inhibition is not properly pronounced. The sound $[\mathrm{k}]$ can only be regulated if at the centre and the end of a phrase. The sound [f] and [v] and the sound [r] are not yet new and have not yet been regulated. The TPM executes the phones that it has not managed to pronounce, such as phonemes $[\mathrm{f}],[\mathrm{v}],[\mathrm{z}]$ and $[\mathrm{x}]$, in a replaceable pattern.
\end{abstract}

Keyword: Analysis, Phonology, Language, Toddler.

\section{A. INTRODUCTION}

Judging by the considerable role of language in life, it can be said that there is no human without language (Kurniawan, 2013). Whenever humans are, that is where language is. The position or role may be more than just a symbol that distinguishes humans and animals (Zen, 2016). Language as a means of communication serves as a tool to work together and convey one's intentions, desires, or feelings. Language is an essential medium of communication both orally and in writing; when communicating, a person does not realise a complicated process related to his language (Banik, 2017). To communicate well, language must be studied well, as speakers of the language must have two competencies: language competence and communicative competence (Wiladati, 2014).

Language competence is knowledge about something abstract, which contains knowledge of rules, parameters or principles, and configurations of language systems (Bruce \& Eriksson, 1998). Linguistic competence is grammatical knowledge that is in the mental 
structure behind the language. Communicative competence is the ability to apply the grammatical rules of a speech to form correct sentences and knows when, where, and to whom the sentences were spoken (Ulfa, 2017). Armed with communicative competence, a person can convey and interpret a message or negotiate to mean interpersonal in a specific context (Sartini, 2012).

Generative phonology is a phonological development initiated by Chomsky and Halle in 1968 (Anggayana, 2018). Generative phonology generally discusses the phonological processes of a language (Jenkins, 2000). Therefore, in the study of generative phonology, the rules of sound change are found. In 1957, Noam Chomsky put forward a new idea in linguistics, namely the generative theory (Sofyan, 2010). Initially, this generative theory studied the language at the level of grammar. This theory can be applied at the phonological level in its development, which is then called generative phonology (Yuliati \& Unsiah, 2018). This generative phonology first appeared in America, and Morris Halle was the first to apply generative principles in phonology (Yanti, 2016). Based on generative theory, which is discussed in generative phonology, the system of rules related to sound and meaning, the phonetic representation of a language, the process of sound changes, and the assumptions that underlie sound changes (Mulyaningsih, 2014).

The rules for sound change in generative phonology include the management of changing features, the rules for segment impingement, the rules for adding/inserting segments, the regulations for uniting segments (coalitions), and the regulations for metathesis (permutation) (Bronson, 2004). These rules are thought to apply universally in all languages. In general, these rules have the following formula: 1) Adding segments; 2) Segment detachment; 3) Kolaisi (unification of segments); 4) Assimilation (Lass, 1984).

\section{B. METHOD}

The method used in this study is a qualitative method by developing FA phonology in toddlers aged 2-2 years and six months. The research design used was longitudinal. The research data source came from the FA through observations, notes, and interviews between the FA and their parents. The data is in the form of primary data, and analysis is carried out to conclude.

\section{RESULT AND DISCUSSION}

At the age of 2 years to 2 years and six months, FA has grown into a healthy little girl, both physically and mentally. In his daily life, apart from communicating with his parents, he has also spoken with other people, such as his father's or mother's family, neighbours, and friends his age. In addition, this child is also often invited to the family place if there are family events and where his mother teaches, so that input on language acquisition development varies considerably (Berent \& Perfetti, 1995).

\section{Acquisition of Vocals}

Vowel sounds that appear based on observations of data obtained for 6 months are as follows.

The vowel sound [a] is the first letter that FA completely controls. The sound appears 
and is pronounced clearly, whether at the beginning, middle, or end of the word. The vowel sound [a] at the beginning of the term appears as in the following comment.

[ada] 'ada' and [Ayah] 'Ayah' The vowel [a] in the middle of the word appears as in the following comment.

[a] [mana] 'mana' and [Tatak] 'Kakak' The vowel [a] at the end appears in the following word.

[a] [apa] 'apa' and [tsuka] 'suka' The vowel sound [i] appears and is pronounced clearly, whether it is at the beginning, middle or end of a word. The vowel sound [i] at the front of the word appears as in the following expression.

[i] [itu] 'itu' and [indomalet] 'indomaret' The vowel sound [i] in the middle of the word appears as in the following comment.

[i] [bibi] 'Bibi' and [sendili] 'sendiri' The vowel sound [i] at the end of a word appears as in the following expression.

[i] [beli] 'beli' dan [pelgi] 'pergi' The vowel sound [u] appears and is pronounced clearly, whether it is at the beginning, middle or end of a word. The vowel sound $[u]$ at the front of a word appears as in the following expression.

[u] [uni] 'uni' The vowel $[\mathrm{u}]$ in the middle of a word appears as in the following expression.

[u] [butan] 'bukan' and [buta] 'buka' The vowel [u] at the end appears as in the following word.

[u] [itu] 'itu' and [mau] 'mau' The vowel sound [e] appears and is pronounced clearly, whether it is at the beginning, middle or end of a word. The vowel sound [e] at the front of the word appears as in the following expression.

[e] [enam] 'enam' and [emang] 'memang' The vowel [e] in the middle of the word appears as in the following expression.

[e] [boneka] 'boneka' and [dedek] 'dedek/ adik' The vowel sound [e] at the end of a word appears as in the following expression.

[e] [e-e] 'he-he' The vowel sound [o] appears and is pronounced clearly, whether it is at the beginning, middle or end of a word. The initial [o] vowel sound appears in the following expression.

[o] [om] 'Om' and [oran] 'orang' The vowel [o] in the middle of the word appears as in the following expression.

[o] [bobok] 'sleep' and [boneka] 'boneka' The vowel sound [o] at the end appears in the following word.

[kado] 'kado' The vowel sound [O] appears and is pronounced well. The data obtained is only on the first term, such as

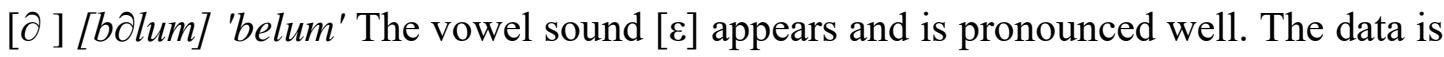
obtained only on the last term, such as:

$[\varepsilon]$ [monet] 'monyet' The vowel sound [ $\mathrm{J}$ ] appears and is pronounced well. The data is obtained only on the last term, such as

[כ] [ijo] 'hijau' The dual vowel sounds that appear are [au], [ai], [ue], and [ua]. The double vowel sound [au] appears as in the following words:

[au] [tau] 'tau' and [mau] 'mau' The second vowel sound [ai] appears as in the 
following words:

[ai] [naik] 'naik' dan [baik] 'baik' The second vowel sound [ue] appears as in the following words:

[ue] [kue] 'kue' The second vowel sound [ue] appears as in the following words:

[ua] [uaף] 'uang'

The diphthong sounds that appear are pronounced with vowels are [au] and [ai]. The diphthong sound $[\mathrm{au}]$ seems as in the following word:

[au] [piso] 'pisau'

A diphthong sound [ai] appears as in the following word.

[ai] [pake] 'pake'

Based on the description and example of the data above, it can be said that FA has mastered all vowel vowels in Indonesian. The vowels [a], [i], [u], [e], and [o] are pronounced well even if they are at the beginning, middle, or end of a word. Allophonic variations exist for each sound, except for [o] and [e] which are the diphthong forms [au] and [ai]. FA has mastered all Indonesian vowels at the age of 2 years and 1 month. The first vowels he mastered were minimal vowels, namely [a], [i], and [u] as described by Dardjowidjojo, then developed to master the front vowels $[\mathrm{i}],[\mathrm{e}],[\varepsilon]$, back vowels $[\mathrm{u}],[\mathrm{o}],[\mathrm{J}$, and the middle

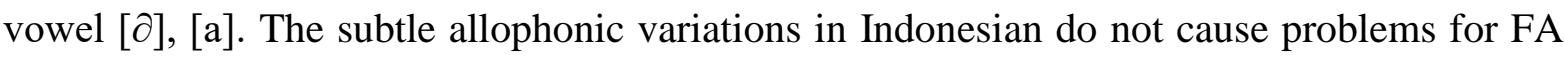
in pronouncing vowel sounds. At the age of 2 years three months, FA has mastered the nondiphthong vowel sequence such as [a-i] in either (Lass, 1992). Vowels [a-u] as in smell, [e-a] as in tiredness, [i-a] as in shit, and [i-i] as in being tied up are also mastered at that age. However, the original diphthong [au] and [ai] as in the river was only controlled by the FA at the age of 2 years six months, whereas the original diphthong [ $\mathrm{i}$ ] , which we rarely find doesn't appear in FA pronunciation.

\section{Acquired Consonants}

Obtaining FA voices at the age of 2 years and five months is not as easy as he understands the acquisition of vowels. The sounds of bilabial pop [p] and [b] are pronounced clearly, whether they are at the beginning, in the middle, or at the end of a word as in the following data.

[peldi] 'pergi' and [dapat] 'dapat'

[b] [Bunda] 'Bunda' and [bilu] 'biru'

The nasal bilabial $[\mathrm{m}]$ and lamino-alveolar sounds are pronounced clearly, both at the beginning, in the middle, and at the end of the word as in the following data:

[mana] 'ke mana' and [mau] 'mau', [lumah] 'rumah'

[boneta] 'boneka' and [Bunda] 'Bunda' The sound of bilabial [w] and lamino palatal [y] is pronounced clearly, either at the beginning, in the middle or at the end of a word as in the following data:

[d] [om Adus] 'om Agus' and [badus] 'bagus'

[g] [gajah] 'gajah'

The bang dorso-velar [k], which is at the beginning or in the middle of a word, is pronounced with a lamino-alveolar [t] sound, but if the sound is located at the end of the term, it is pronounced $[\mathrm{k}]$ as in the following data: 
[t] [temali] 'kemari' and [tuda] 'kuda' [tue] 'kue' [buta] 'buka'

[matan] 'makan' and [belatan] 'belakang'

[k] [Tatak] 'Kakak'

At the age of 2 years five months, the sound [k] in the middle has been pronounced correctly; for example, big brother is pronounced [takak].

The palatal affricate sound [c] if it is located at the beginning of the word is pronounced correctly, but if the sound is located in the middle, it is pronounced with [t] as in the following data.

[t] [cutup] 'cukup' and [celita] 'cerita'

[c] [kuting] 'kucing'

The palatal affricate sound [j] is sometimes pronounced well and sometimes is pronounced labiodental block [d], as in the following data.

[j] [juda] 'juga' dan [ijo] 'hijau'

[d] [danan] 'jangan'

The lamino-allviolar fricative sound $[\mathrm{s}]$ is sometimes pronounced clearly, and sometimes it is pronounced as labiodental block $[\mathrm{t}]$, and the fricative sound $[\mathrm{z}]$ is pronounced [j] as in the following data.

[masih] 'masih' and [tampus] 'kampus'

[tsuka] 'suka' and [tekolah]

The vibrating sound $[\mathrm{r}]$ has not appeared. Therefore, the sound is pronounced with a side or lateral sound [1] as in the following data.

[balu] 'baru' and [bilu] 'biru'[lumah] 'rumah'

At the age of 2 years to 2 years six months, it seems that there are consonants that have been mastered by FA well and are pronounced clearly; there are also consonants that have been mastered but are still fluctuating with other sounds, and there are even sounds that they have not mastered at all. However, in pronouncing certain phonemes, the observations show that FA often performs a substitution pattern. The substitution pattern that appears is as follows:

Shakes become lateral, for example:

$\begin{array}{lll}\text { [rumah] } & \rightarrow & \text { [lumah] } \\ \text { [lari] } & \rightarrow & \text { [lali] }\end{array}$

Alveopalatal nasals become dental nasals, for example:

$\begin{array}{lll}{[\tilde{n} a \tilde{n} i]} & \rightarrow & \text { [nani] } \\ \text { [ñapu] } & \rightarrow & \text { [napu] }\end{array}$

Heavy inhibition velar becomes bilabial inhibition, for example:

$\begin{array}{lll}\text { [bagus] } & \rightarrow & \text { [badus] } \\ \text { [gatal] } & \rightarrow & \text { [datal] }\end{array}$

The nasal Velar at the beginning and middle of the syllable becomes the dental nasal, for example:

$$
\begin{array}{lll}
\text { [buya] } & \rightarrow & \text { [bunga] } \\
\text { [ } \text { numpet] } & \rightarrow & \text { [numpet] }
\end{array}
$$

Labiodental light fricative at the beginning of a syllable becomes a mildly inhibited bilabial, for example: 


\section{[fanta] $\rightarrow \quad$ [panta]}

Dental fricatives at the beginning of the syllable become light dental stops or light fricatives, for example:

$\begin{array}{lll}\text { [sekolah] } & \rightarrow & \text { [tetolah] } \\ \text { [susu] } & \rightarrow & \text { [tsutsu] }\end{array}$

Based on the description and example of the data above, it seems that FA has mastered the sound of consonants $[\mathrm{p}],[\mathrm{b}],[\mathrm{t}],[\mathrm{d}],[\mathrm{h}],[\mathrm{m}],[\mathrm{n}],[\mathrm{l}],[\mathrm{w}],[\mathrm{y}],[\mathrm{k}],[\mathrm{s}],[\eta]$ at the age of 2 years and 1 month. FA only masters the sounds $[\mathrm{k}],[\mathrm{s}],[\eta]$ if they are located at the end of a word. FA has not yet mastered the light velar sound at that age, [k], if it is located in the middle and end of a word. The FA only mastered the sound after two years and five months.

The sound of a heavy velar stop (velar voice stop), [g], is still often pronounced with [d], especially if it appears in the middle like Adus 'Om Agus', but if it is located at the beginning, it is pronounced with [g] like itching. The fricative sound [s] at the front of a word is often pronounced as [t] or [ts], but at the end of the term, it is pronounced with a fricative [s]. By the age of 2 years six months, the light affricative sound [c] was pronounced well as in the experiment, and by the age of 2 years six months, the sounds became more explicit and pronounced well. Until the period of 2 years and six months, it seems that FA has not been able to pronounce consonant groups, except for [mb] and [ $\eta \mathrm{g}]$ in words Ms The consonant groups are all pronounced with a single consonant.

\section{Factors Affecting Phonological Acquisition}

The observations show that the emergence of various variations in the acquisition of phonology is mainly due to the imperfectness of the FA speech tool. Even though the author has tried to provoke consonants that have not appeared in the pronunciation, FA can still pronounce the consonants. This seems to be in line with Lenneberg's opinion, which states that children's language development follows inexorable biological development. A child cannot be forced or encouraged to say something if his physical abilities are not yet possible. On the other hand, if a child is biologically able to say something, he cannot be prevented from pronouncing it either.

Another factor that influences the acquisition of FA phonology is the stimulus from the family or the surrounding environment. Some of the data that the authors have obtained shows that certain sounds appear through imitation, such as the pronunciation of the diphthong [au] and [ai] in the words if, buffalo and those that have not appeared are pronounced FA with [kebo], [kalo], and [pake]. The absence or absence of diphthongs seems to be due to articulation difficulties, and the input received by the FA was often in the form of monophthongs. Speakers around the FA in their daily lives pronounce these sounds as monophthongs ([kebo], [kalo], and [pake]) so it can be understood if FA also pronounces it with monophthong sounds too.

Mastery of FA consonants does not seem as easy as mastering vowels. There is a consonant sound that he has mastered; some still fluctuate with other sounds, and there is even a sound (sound $[\mathrm{r}]$ ) that he has never been able to pronounce. For more details, consider the following Table 1: 
ARTIKEL

Table 1 Control of Konsnan Sounds

\begin{tabular}{|c|c|c|c|c|c|c|}
\hline \multirow{2}{*}{$\begin{array}{c}\text { Articulation } \\
\text { Way }\end{array}$} & \multicolumn{6}{|c|}{ Articulation Area } \\
\hline & Bilabial & Labio-dental & Alveolar & Alveo-Palatal & Velar & Glotal \\
\hline \multirow[t]{2}{*}{ Resistor } & $\mathrm{P}$ & $\mathrm{t}$ & & & (k) & $?$ \\
\hline & $\mathrm{b}$ & $\mathrm{d}$ & & & (g) & \\
\hline \multirow[t]{2}{*}{ Fricative } & & (f) & $\mathrm{s}$ & & $(\mathrm{x})$ & $\mathrm{H}$ \\
\hline & & (v) & $(\mathrm{z})$ & & & \\
\hline \multirow[t]{2}{*}{ Affricative } & & & & $\mathrm{c}$ & & \\
\hline & & & & $\mathrm{j}$ & & \\
\hline Nasal & $\mathrm{M}$ & & $\mathrm{N}$ & $(\tilde{\mathrm{n}})$ & & \\
\hline Lateral & & & & $\mathrm{L}$ & & \\
\hline Shakes & & & & $(\mathrm{r})$ & & \\
\hline Semi Vocal & $\mathrm{W}$ & & & & $\mathrm{y}$ & \\
\hline
\end{tabular}

Source: Data proceed

The consonant chart above shows that the phonemes that have been mastered by FA well are [p], [b], [t], [d], [s], [h], [c], [j], [m], [n], [y], [1], [w], and [y]. Bilabial [p] and [b] popping sounds, bilabial [m] and lamino-alviolar [n] nasal sounds, bilabial $[\mathrm{w}]$ and lamino palatal $[\mathrm{y}]$ popping sounds, and lamino-alveolar [t] and [d popping sounds ] pronounced clearly.

Consonants that have appeared but are still fluctuating with other sounds are $[\mathrm{t}],[\mathrm{s}]$, [c], [j], and [y]. If the lamino-allviolar [s] fricative sound is at the end of a word, it is pronounced FA. However, if the sound comes at the beginning of a syllable, it is often pronounced [t] or [ts], for example [abis] in [habis] 'habis'. There is also a heavy affricative sound [j] that is spelled as [d], for example [danan] pada [jangan] in 'jangan'. The sound of the velar inhibitory is pronounced as labiodental inhibition [d], and the velar inhibitory sound [ $\mathrm{k}$ ] is pronounced as labiodental inhibition [ $\mathrm{t}$ ], for example [badus] in [bagus] 'bagus', [tamal] in [kamar] 'kamar'. Voiceless velar stop sound, [k] can only be mastered if it is located in the middle and end of a word at 2 years and 5 months. By the age of 2 years 5 months the light affricative sound [c] was pronounced well as in the experiment, and by the age of 2 years 6 months the sounds became clearer and pronounced well.

The fricative sounds [f] and [v] have not appeared and are well controlled by FA so they are pronounced with [p] like [panta] in [fanta] 'fanta' and [fitting] in [vase] 'flower vase'. The sound of fricative $[\mathrm{x}]$ was not found in the data, so perch did not appear. Vibration sound [r] that has not yet appeared is pronounced with a lateral sound [1], for example [election] in [blue] 'blue'. FA's ability to pronounce the phonemes [f], [v], [z], and $[\mathrm{x}]$ is not yet visible because the frequency of use in Indonesian is minimal. FA performs a substitution pattern to pronounce certain phonemes. The pattern replacement that appears is related to the phonetic proximity; that is, another phonetically adjacent sound replaces a sound. For example, the vibrating sound becomes lateral like [rumah] be [lumah].

\section{CONCLUSION}

In general, the acquisition of FA phonology follows an order universal following the theory of language acquisition. The universal concept of Jakobson (in Dardjowijojo, 2012: 238) is found in the acquisition of FA phonology, both in the acquisition of vowels and consonants. In the case of vowels, three central vowels appear first, namely [i], [u], and [a]. Such a contrast system is called the minimal vowel system and is present in all languages. In the case of consonants, inhibit is mastered before fricative, and fricative is mastered before affricate. The 
nasal sound begins with the bilabial nasal [m], followed by the nasal Velar [n]. Obtaining inhibitory consonants starts from bilabial to alveolar, then to velar. The lateral sound [1] has been mastered, while the vibrating sound [r] has not. The liquid sound in the form of lateral [1] appears first after the light hitch sound, while the sound [r] has not yet appeared because it is suspected that it is more difficult to pronounce it.

\section{REFERENCES}

Anggayana, I. W. A., \& Sari, N. L. K. J. P. (2018). Kemampuan Berbicara Bahasa Inggris Mahasiswa Akomodasi Perhotelan: sebuah Kajian Fonologi. Jurnal Manajemen Pelayanan Hotel, 1(1), 8-14.

Banik, L. A. (2017). Fonologi Bahasa Kanaumana Kolana. Retorika: Jurnal Ilmu Bahasa, 3(1), 145-158.

Bronson, B. S. (2004). Phonetically based phonology. Cambridge University Press.

Bruce, G., Engstrand, O., \& Eriksson, A. (1998). De svenska dialekternas fonetik och fonologi år 2000 (Swedia 2000)-en projektbeskrivning. Bidrag till den, 6, 12-16.

Cohn, A. C. (1993). Nasalisation in English: phonology or phonetics. Phonology, 10(1), 4381.

Jenkins, J. (2000). The phonology of English as an international

Kurniawan, P. T. (2013). Analisis Fonologi Dan Leksikologi Bahasa Jawa Di Desapakem Kecamatan Gebangkabupaten Purworejo. ADITYA-Pendidikan Bahasa dan Sastra Jawa, 2(4).

Lass, R. (1984). Phonology: An introduction to basic concepts. Cambridge University Press.

Lass, R. (1992). Phonology and morphology. The Cambridge history of the English language, 2, 1066-1476.

Mulyaningsih, D. H. (2014). Perbandingan Fonologi Bahasa Indonesia dan Bahasa Mandarin. BAHTERA: Jurnal Pendidikan Bahasa dan Sastra, 13(1), 1-10.

Ohala, J. J. (1990). There is no interface between phonology and phonetics: a personal view. Journal of phonetics, 18(2), 153-171.

Sartini, N. W. (2012). Bahasa pergaulan remaja: Analisis fonologi generatif. Jurnal Ilmu Humaniora, 12(2), 122-132.

Sofyan, A. (2010). Fonologi Bahasa Madura. Humaniora, 22(2), 207-218.

Ulfa, M. (2017). Pemerolehan Fonologi, Morfologi, dan Sitntaksis Anak Usia 2, 5-3 Tahun. JOURNAL PROCEEDING, 1(1).

Wiladati, R. A. (2014). Bahasa Jawa di Kabupaten Batang (Tataran Fonologi dan Leksikon). Sutasoma: Jurnal Sastra Jawa, 3(1).

Yanti, P. G. (2016). Pemerolehan bahasa anak: kajian aspek fonologi pada anak usia 2-2, 5 tahun. Jurnal Ilmiah Visi, 11(2), 131-141.

Yuliati, R., \& Unsiah, F. (2018). Fonologi. Universitas Brawijaya Press.

Zen, A. L. (2016). Perubahan Fonologis Kosakata Serapan Sansekerta dalam Bahasa Jawa (Analisis Fitur Distingtif dalam Fonologi Transformasi Generatif) (Doctoral dissertation, Diponegoro University). 